\title{
Effectiveness of Rhizobial Strains on the Faba Bean Development and Yield in Soddy Podzolic Soils
}

\author{
Livija Zarina ${ }^{1}$, Ina Alsina ${ }^{2}$, Aija Vaivode ${ }^{1}$ \\ ${ }^{1}$ Institute of Agricultural Resources and Economics, ${ }^{2}$ Latvia University of Agriculture, Jelgava, \\ Contactpoint. Address: Zinatnes 2, Priekuli, LV-4126, Latvia.
}

\begin{abstract}
In the frame of $\mathrm{EU} 7^{\text {th }}$ Research Framework Programme of The European Union project EUROLEGUME (Enhancing of legumes growing in Europe through sustainable cropping for protein supplay for food and feed) two Rhizobium leguminosarium strains alone and in mixture were examinated to evaluate the influence on yield formation of faba bean (Vicia faba L.) 'Lielplatones'. The field experiment was carried out at the Institute of Agricultural Resources and Economics between 2014 -2016 in the organic cropping system field. The beans seeds were treated with rhizobia fungi by soaking in bacteria suspension for 30 minutes before sowing. A plant high was measured at the beginning of flowering (BBCH 61- 64), at the beginning of forming pods (BBCH 71- 75) and at the beginning of maturity (BBCH 81- 85).

The inoculation of plant seeds promotes a slight increase in the plant length. The highest yield was from seeds inoculated with strain $R 2$. There were no significant differences between tested strains. The results of this investigation indicate that rhizobium inoculation is a recommendable management tool for faba beans generally but effectiveness of rhizobial strains strongly depending climate conditions. Seed treatment with Rhizobium contributed to an increase in the quantity of nitrogen in the soil.
\end{abstract}

Keywords: grain legumes, organic farming, soil, nitrogen.

\section{INTRODUCTION}

Grain legume crops play significant roles in the human diet and animal feed and the environment, but only the fraction of the species in this diverse group of plants is currently exploited in agriculture [3].

Faba bean (Vicia faba L.) is among the oldest crops in the world [14] with a long tradition of cultivation in the temperate zone of the northen hemisphere [5]. Because of comperatively good adaptivity to groving conditions $[9,14]$ they are widely in different agroclimatical regions [12]. Due to their great resistance to low temperatures, they are, among leguminous plants, the best adapted to colder climates such as the Northern parts of Europe, and represent to the inhabitants of that region a source of energy, protein, folic acid, niacin, vitamin C, magnesium, potassium, iron and dietary fiber [6].

Faba beans are high- yield crop whose botheconomic and ecologic role is very significant; they contain up to $35 \%$ of crude protein, approximately $50 \%$ of carbohydrate and no more than $15 \%$ of crude lipid $[1,7,10,11]$. Faba bean responds to and changes its environment by altering on-site soil fertility, microclimate, and co-habitats of wild flora and fauna [9] and is an excellent crops for cropping systems because of its unique ability to fix atmospheric nitrogen symbiotically which is heavy depends on sufficient populations of effective rhizobia [8]. The inoculation of the legume seed material with active nitrogen fixing bacteria strains before sowing has a significant role for the increase of the legume yield $[1,13]$. Inoculation can improve crop yields in cases where appropriate rhizobia are not present in the soil or the soil contains a significant proportion of nonnodulating or ineffective nitrogen-fixing strains. Inoculation of legume seeds with Rhizobium affects soil microbial community and processes, especially in the rhizosphere [13].

Although the global average grain yield of faba bean has almost doubled over the past 50 years, the total area sown to the crop has declined by $56 \%$ over the same period, owing to the cheap availabilty of fertilizers and competition with policy-baked cereal crops [8]. The new EU policy of agriculture promoted a sharp increase of spring field bean (Vicia faba L.) sowing area in Latvia. The total area under faba beans increased 19 times from 2010 to 2015- from 1.3 thou ha in 2010 to 25.9 thou in 2015 [11]. Taking into account that currant research trends in legumes are focused on new methodologies involving genetic and - omic studies, as well as new approaches to the genetic improvement of these species, inclyding the ralationships with their symbiotic rhizobia [5], the aim of this studies was to test new commercial Rhizobium inoculants effectivity for faba bean 'Lielplatones'. 


\section{MATERIALS AND METHODS}

Site and soil description. Three years experiments were performed in organically managed sodddy podzolic loamy sandy soils field at Institute of Agricultural Resourses and Economics (Priekuli, $\left.57^{\circ} 31^{\prime} 92^{\prime \prime} \mathrm{N}, \quad 25^{\circ} 36^{\prime} 26^{\prime \prime} \mathrm{E}\right)$ during 2014-2016. A measurement of soil $\mathrm{pH}$ and nutrient content was performed every year by the State Plant Protection Service of Latvia corresponding methodology traditionally adopted for agricultural experimental fields: for soil $\mathrm{pH}$ detection were used $\mathrm{pH}-$ potentiometrically in a $1 \mathrm{M} \mathrm{KCl}$ suspension method, content of organic matter in soil- by Tyurin's method, in \%, plant available phosphorus and potassium in soil by Egner-Riehm, nitrogen- by Kjeldahl method (standard LVS EN/IEC 17025:2005). The main soil agrochemical parameters are presented in Table 1.

Table 1.

Soil characteristics of experimental fields

\begin{tabular}{lccc}
\hline \multicolumn{1}{c}{ Soil characteristic: } & 2014 & 2015 & 2016 \\
\hline $\mathrm{pH}_{\mathrm{KCl}}$ & 5.9 & 5.7 & 5.6 \\
humus, $\mathrm{g} \mathrm{kg}^{-1}$ & 19 & 24 & 19 \\
$\mathrm{P}_{2} \mathrm{O}_{5}, \mathrm{mg} \mathrm{kg}^{-1}$ & 142 & 139 & 139 \\
$\mathrm{~K}_{2} \mathrm{O}, \mathrm{mg} \mathrm{kg}^{-1}$ & 148 & 171 & 135 \\
$\mathrm{~N}-\mathrm{NO} 3, \mathrm{mg} \mathrm{kg}^{-1}(0-20 \mathrm{~cm})$ & 2.1 & 6.1 & 2.7 \\
$\mathrm{~N}-\mathrm{NO} 3, \mathrm{mg} \mathrm{kg}^{-1}(20-40 \mathrm{~cm})$ & 3.8 & 3.3 & 3.5 \\
$\mathrm{~N}-\mathrm{NH} 4, \mathrm{mg} \mathrm{kg}^{-1}(0-20 \mathrm{~cm})$ & 2.2 & 2.4 & 1.9 \\
$\mathrm{~N}-\mathrm{NH} 4, \mathrm{mg} \mathrm{kg}^{-1}(20-40 \mathrm{~cm})$ & 0.6 & 0.7 & 1.4 \\
\hline
\end{tabular}

In the trial area, the field crops have been cultivated according to the principles of organic farming since 2003. Faba beans were grown in sixfield crop rotation: spring barley with clover as undersown-red clover-spring cereals-winter ryepotatoes-pulses. Evaluation of phenology of crops by recording of dates of the beginning of emergence (when at least $50 \%$ of cotydelons were opened) and beginning of flowering (when at least $50 \%$ of flowers were opened) was carried out. For measurements 10 plants per plot were selected.

\section{Field and crop management}

Soil tillage technology in crop rotation was based on the traditional manners-the mouldboard ploughing to a depth of $20 \mathrm{~cm}$ in autumn and cultivations before sowing in spring. Clover was cut and ploughed into the soil in the beginning of July. Straw and crop residues were not removed from the field. Weeds were controlled in the spring cereals and pulses after sowing and in the rye field at the end of April or in the beginning of May by spring-tine harrowing. In the potato field inter-rows $(70 \mathrm{~cm}$ spacing) were harrowed and cultivated three to four times, respectively.

As the basic soil fertility management measure was green manure. Additionally the enriching of soil was achieved by cultivating of clover as the improvement through the nitrogen fixation, as well as by turning the plants residues into the soil.

Weather conditions
The weather conditions during research period are shown in Figure 1. They were different. Vegetation period's beginning in 2014 was fixed April 17th, 2015- 21st, but 2016- April 3rd. Respective local average precipitation is about $690 \mathrm{~mm}$ and generally there is a moisture natural surplus. The spring of 2016 differed among other springs with less precipitation in the beginning of vegetation. May was also extremely warm. Unexpectedly dry and warm was July 2014 that made negative influence on forming of pods.

As the coldest was 2015 with $12.7{ }^{\circ} \mathrm{C}$ as an average for six year period.
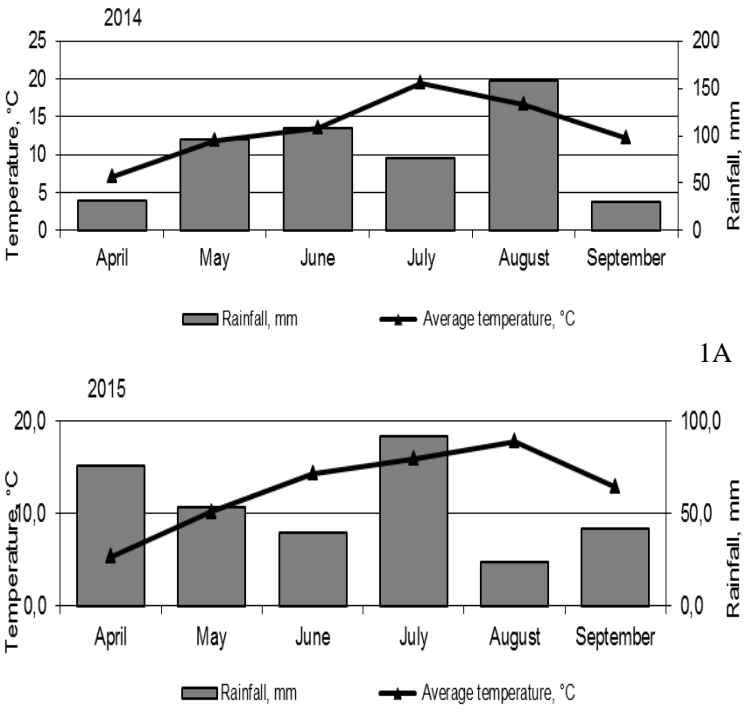

1B

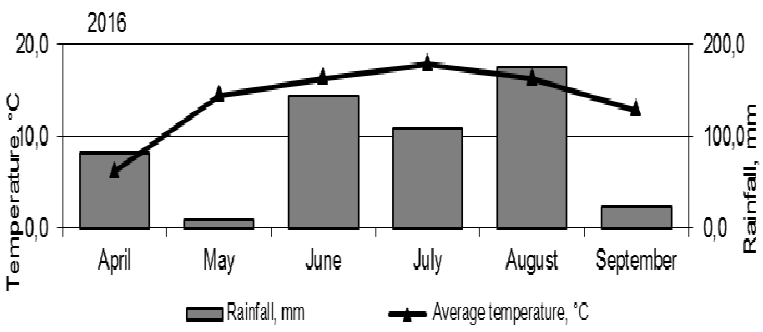

$1 \mathrm{C}$

Fig.1. Monthly total precipitation and average air temperature during 2014 - 2016 (1A- 2014, 1B- 2015, 1C- 2016).

\section{Innoculation, measuring and soil sampling}

Three Rhizobium leguminosarum strains- RI, R2, R3 (mixture of R1 and R2) were obtained from the Rhizobium collection of the Latvia University of Agriculture of Institute of Soil and Plant Science. The inoculants were mixed with moistened bean's seeds by soaking in bacteria suspension for 30 minutes before sowing. Control seeds weren't inoculated with Rh. leguminosarum strains. A plant high was measured at the beginning of flowering (BBCH 6164 ) and at the beginning of forming pods (BBCH 71$75)$ and at the beginning of maturity (BBCH 81- 85).

The soil samples were taken from points randomly selected points of each treatment from the 0-20 $\mathrm{cm}$ and $20-40 \mathrm{~cm}$ soil layer using an auger with a $1 \mathrm{~cm}$ diameter. The composite sample was carefully 
mixed. To avoid contamination of soil samples, the preventive measures accordingly to the guide were taken. Soil samples had been kept in cold until they were analysed in the laboratory.

\section{RESULTS AND DISCUSSION}

Effectiveness on the plant development

The inoculation of plant seeds promotes a slight increase in the plant length only in 2014 when in the period till the beginning of flowering was more precipitation than other two experimental years (Fig.2). In this year plants reached the greatest length$112-115 \mathrm{~cm}$, which is typical for variety 'Lielplatones'. Plant height in 2015 was $90-95 \mathrm{~cm}$, but in 2016- 55-62 cm only. The obtained data indicate significant negative impact of humidity deficit at the beginning of faba bean development, as it was fixed in May 2016 when rained down $9.8 \mathrm{~mm}$ only. There were no differences found between the tested Rhizobium strains.

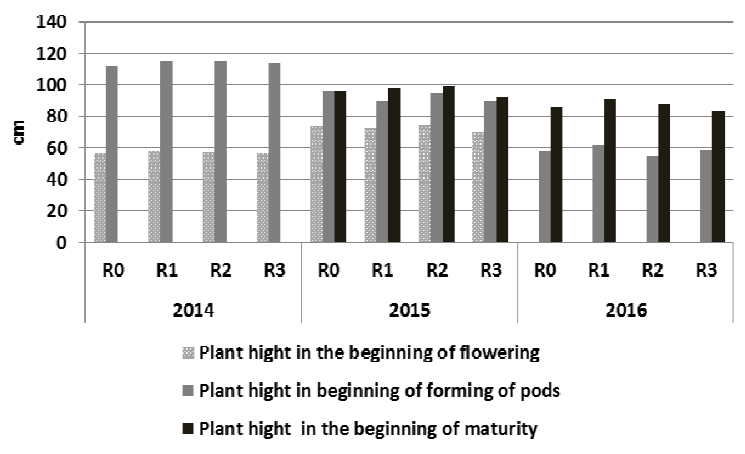

Fig. 2. Plant height at different Vicia faba L. development stages depending Rhizobium strain

Figure 3 shows that, depending on the year inoculation with Rhizobium influencing the forming of pods. Strain R2 reflected higher positive impact on the forming of pods per plant in 2014 and 2016 but strain R1 in 2015. Low (in 2015) or negative effect (2014 and 2016) fixed after inoculation with R3. The largest number (8.8) of pods per plant on average in all variants was formed in 2016, when the plants as compared to the other two years were the shortest. Because accordingly Bishop et al [2] it is difficult to reliably identify key stages of reproductive development in field conditions, to explain effects requires long term experiments.

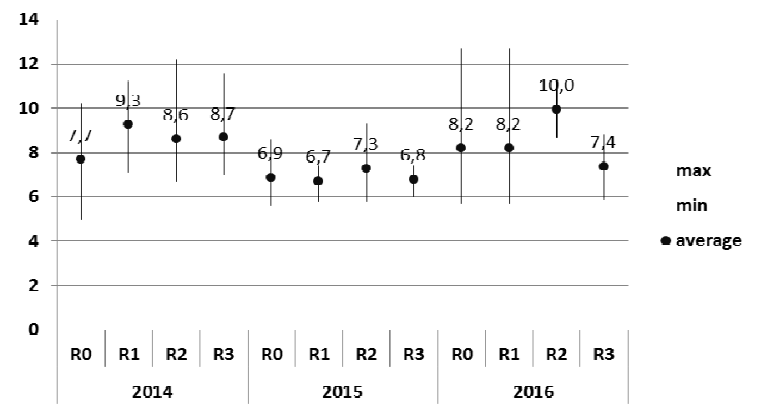

Fig. 3. Amont of pods per plant of Vicia faba L 'Lielplatones' depending Rhizobium strain

\section{Effectiveness on the yield}

Despite the fact that most of pods were formed in 2016, on average the highest faba bean yield (in average $3.2 \mathrm{t} \mathrm{ha}^{-1}$ for all variants) was obtained in the season of 2015 (Fig. 4). Results show that the crucial role played climatic conditions in July and August; in

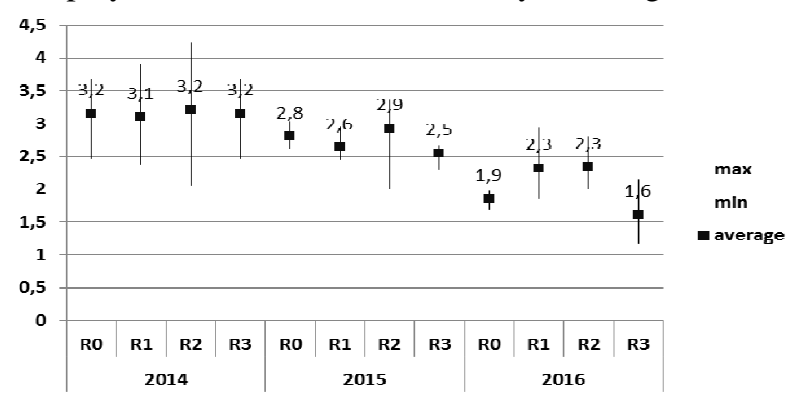

Fig. 4. The yield of Vicia faba L 'Lielplatones' depending Rhizobium strain

2015 when was obtained higher yield, July was characterized by moderate monthly temperature $\left(15.9^{\circ} \mathrm{C}\right)$ and rainfall $(91.5 \mathrm{~mm})$, followed by relatively dry and warm August. In the other two years in those months was a drastic deviation compared to long term average data.

In contrast to other author's [14] data inoculation with Rhizobium did not affect the yield formation; there was no significant influence of inoculation with Rhizobium on the yield of Vicia faba L 'Lielplatones' fixed.

Effectiveness on $N$ content in soil

As affirmed by several researchers [4] also in our experiments inoculation with Rhizobium contributed to the increase of nitrogen in the soil both, $0-20 \mathrm{~cm}$ and 20-40 cm layer (Fig 5-7). For all examined strains inoculations positive effects most apparent was in 2014. Inoculation positive effects most apparent was using strain R2.

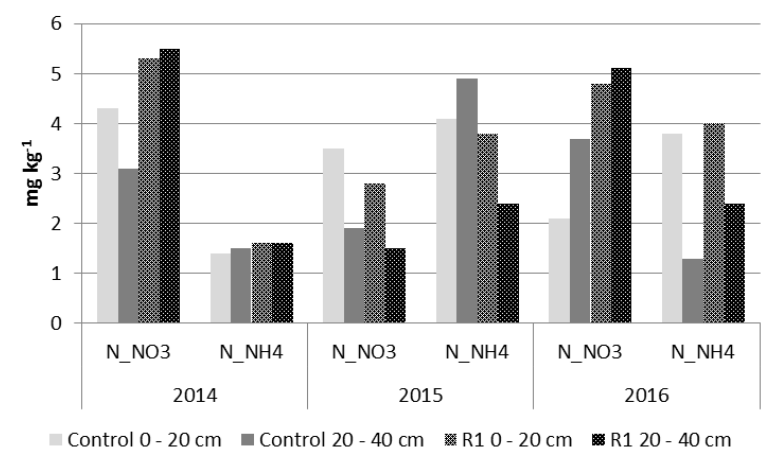

Fig. 5. Effect of R 1on soil nitrogen content 


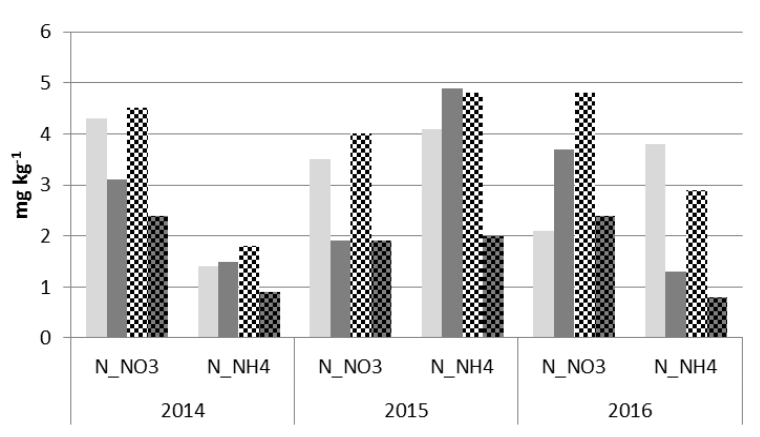

$=$ Control $0-20 \mathrm{~cm}=$ Control $20-40 \mathrm{~cm} \quad$ \& R2 $0-20 \mathrm{~cm}$ R2 $20-40 \mathrm{~cm}$

Fig. 6. Effect of R 2 on soil nitrogen content

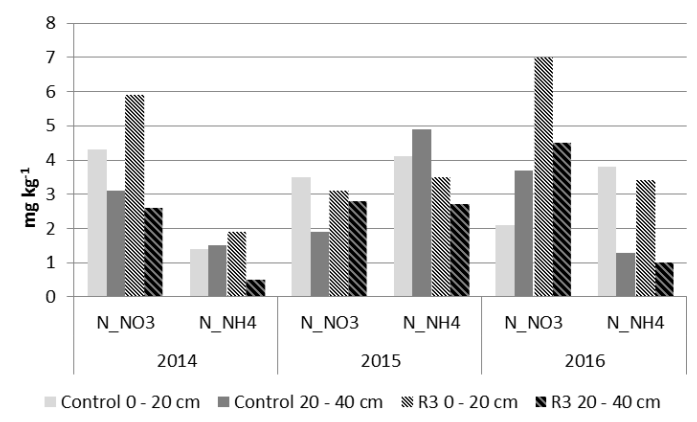

Fig. 7. Effect of R 3 on soil nitrogen content

\section{CONCLUSION}

The results of this investigation indicate that rhizobium inoculation is a recommendable management tool for faba beans generally but effectiveness of rhizobial strains strongly depending climate conditions.

Neither strain R1 and R2, nor mixture of them did not provide a significant yield increase for faba bean 'Lielplatones'.

Faba bean 'Lielplatones' seed treatment with Rhizobium leguminosarium contributed to an increase in the quantity of nitrogen in the soil.

\section{ACKNOWLEDGMENTS}

Authors acknowledge scientific research Project 'Enhancing of Legumes Growing in Europe through Sustainable Cropping for Protein Supply for food and Feed' (EUROLEGUME). Agreement No 613781, which provided financial support for this study.

\section{REFERENCES}

[1] Ansevica, A., Alsina, I., Steinberga, V. The evaluation of rhizobium leguminosarum strains effectiveness in field beans (Vicia faba L.) at different soil microbiological activity. Agricultural Sciences (crop sciences, animal sciences). 2008, pp.71-75.

[2] Bishop, J. G. Potts, J.G., Jones, H.E. HEAT STRESS Susceptibility of Faba Bean (Vicia faba L.) to Heat Stress During Floral Development and Anthesis. Journal of Agronomy and Crop Science, 2, Version of Record online: 21 MAR 2016.

[3] Cernay, C., Pelzer, E., Makowski, D. A global experimental dataset for assessing grain legume production. Sci. Data 3, 2016, 160084.

[4] Denton, M., Pearce, D., Peoples, M. Nitrogen contributions from faba bean (Vicia faba L.) reliant on soil rhizobia or inoculation. Plant \& Soil. 2013, Vol. 365, Issue 1/2, pp. 363374.

[5] Due, G., Aleksic, J.M., Mikic, A., Paull, J., Redden, R.J., Sass, O., Stoddard, F.L.,Vandenberg, A., Vishnyakova, M., Torres, A.M. Grain legumes, De Ron, A.M (ed.). Handbook of Plant Breeding 10, Springler Science+Business Media New Yourk, 2015, pp. 141-178.

[6] Giménez, M., González, R. J., Wagner, J., Torres, R., Lobo, M. O., Samman, N. C. Effect of extrusion conditions on physicochemical and sensorial properties of corn-broad beans (Vicia faba) spaghetti type pasta. Food Chemistry. 136 (2), 538-545.

[7] Hawthorne, W. Pulses nutritional value and their role in the feed industry. Edition 2, Pulse Australia Pty Ltd, 2006.

[8] Jensen, E.S., Peoples, M.B., Hauggaard-Nielsen. H. Faba bean in cropping systems. Field Crops Research 115 (3), pp. 203-216.

[9] Kopke, U., Nemecek, T. Ecological services of faba bean. Field Crops Research, 115, 2010, pp. 217-233.

[10] Macarulla, M. T., Medina, C., De Diego, M. A., Chavarri, M., Zulet, A. M., Martınez, J. A., Noel- Suberville, C., Higueret, P., \& Portillo, M. P., Effects of the whole seed and a protein isolate of faba bean (Vicia faba) on the cholesterol metabolism of hyper-holesterolaemic rats. British Journal of Nutrition, 85 (5), 2001, pp 607-621.

[11] Proskina, L., Cerina, S., Zeverte-Rivza, S.2016. Faba beans as an alternative protein source for broiler chicken feed. Proceedings of the 2016 International Conference "ECONOMIC SCIENCE FOR RURAL DEVELOPMENT', 41, Jelgava, LLU ESAF, 21-22 April 2016, pp 265-272.

[12] Salem, S. Alghamdi, 2009. Chemical Composition of Faba Bean (Vicia faba L.) Genotypes under Various Water Regimes. Pakistan Journal of Nutrition, 8: 477-482.

[13] Siczek, A., Lipiec, J. Impact of Faba Bean-Seed Rhizobial Inoculation on Microbial Activity in the Rhizosphere Soil during Growing Season. Int. J. Mol. Sci. 2016, 17, 784

[14] Singh, A.K., Bharati, R.C., Manibhuskan, N.C., Pedpati, A. An assesment of faba bean (Vicia faba L.) currant status and future prospect. African Journal of Agricultural Research, 8, 2013, pp. 6634-6641. 